\title{
The Impact of Using the Total Cost of Ownership (TCO) Account for a Reusable Wooden Flat Pallet in Its Operational Phase on Respecting the Principles of Sustainable Development
}

\author{
Mariusz Jedliński ${ }^{1}$ (D) and Mariusz Sowa ${ }^{2, *(D)}$ \\ 1 Faculty of Economics and Transport Engineering, Maritime University of Szczecin, ul. H. Pobożnego 11, \\ 70-507 Szczecin, Poland; m.jedlinski@am.szczecin.pl \\ 2 Institute of Management, University of Szczecin, ul. Cukrowa 8, 71-004 Szczecin, Poland \\ * Correspondence: mariusz.sowa@usz.edu.pl
}

Citation: Jedliński, M.; Sowa, M. The Impact of Using the Total Cost of Ownership (TCO) Account for a Reusable Wooden Flat Pallet in Its Operational Phase on Respecting the Principles of Sustainable

Development. Resources 2021, 10, 116. https://doi.org/10.3390/

resources10110116

Academic Editors: Eva Pongrácz,

Eleftherios I. Thalassinos,

Kesra Nermend and Anna Borawska

Received: 25 August 2021

Accepted: 8 November 2021

Published: 10 November 2021

Publisher's Note: MDPI stays neutral with regard to jurisdictional claims in published maps and institutional affiliations.

Copyright: (c) 2021 by the authors. Licensee MDPI, Basel, Switzerland. This article is an open access article distributed under the terms and conditions of the Creative Commons Attribution (CC BY) license (https:/ / creativecommons.org/licenses/by/ $4.0 /)$.

\begin{abstract}
Despite the commonly observed trend towards mechanization and automation of operational processes, the potential benefits of wooden pallets as an essential element of the infrastructure of logistic processes are often overlooked in considerations related to sustainable development. Aspects that are mentioned more often include the very idea of the economy itself (circular economy), characteristics of logistics (green), features of the supply chain itself (sustainable) or expectations towards transport (ecological). The authors believe that the idea of total cost of ownership (TCO) in relation to wooden pallets can be a key component of holistic thinking in terms of sustainable development. In a situation where in relation to logistics, reasonable expectations for developing sustainable supply chains are made, paying attention to such a common logistic facility, namely a cargo pallet, which is given so little attention in research, is, in the opinion of the authors, absolutely justified. Therefore, the article presents an original approach to the problem of aggregation of all costs that cargo pallets generate in their operational life cycle, using the total cost of ownership (TCO) analysis methodology. The main goal of the article, however, is to show that the total cost of ownership of a pallet (not only owning it) can become an effective tool used to significantly reduce the costs of logistic activity of enterprises (as well as whole supply chains) and support the idea of sustainable development in practice. Using the primary data from questionnaire research, the focus was on considerations that were of identification character (cognitive and explanatory considerations), which are typical for basic research that aims to explain given phenomena. Thus, the presented cognitive process covers two main areas, namely: the general theory of sustainable development and the specificity of wooden pallets as carriers used in goods trading in terms of their total costs of ownership.
\end{abstract}

Keywords: sustainable development; logistic infrastructure; wooden pallets pool; pallet management; total cost of ownership; sustainable principle

\section{Introduction}

In the modern economy, each responsibly implemented economic process, apart from the necessity to ensure its effectiveness and efficiency, requires a synergistic consideration of aspects of sustainable development. These aspects should be understood both from the angle of binding regulations, norms, and rules (e.g., Rio Declaration on Environment and Development) and numerous publications e.g., [1,2]. It is expected that it will be a conscious and voluntary commitment of each economic entity to exercise utmost diligence in terms of economic development (which is an obligation towards a management board, employees, stockholders, or shareholders), with respect to and protection of environmental processes and natural resources (which, in turn, is a commitment to future generations), and, finally, for the common good of society (so that both individuals and the entire community benefit from economic development and care for the environment). 
At the level of strategic and tactical activities, one undoubtedly can see ample evidence of such a responsible approach, starting from, e.g., implementing systems based on a collection of ISO series of standards, adopting the principles of Corporate Social Responsibility (CSR), certifying logistic facilities (buildings) with Leadership in Energy and Environmental Design (LEED) or Building Research Establishment: Environmental Assessment Method (BREEAM) [3-5]. In the case of operational activities, however, a certain inconsistency can be observed. One example includes the role of logistic carriers, namely reusable flat wooden pallets. One can assume that this is caused by the following factor: high universality (and thus a kind of "cost imperceptibility") of this carrier, its relative cheapness (low cost of obtaining it), and visible lack of interest in high quality (relying only partially on licensed pallets). That is why an important scientific challenge is to propose a balanced approach to a life cycle of a pallet from the angle of total cost of ownership. The very understanding of a "cargo pallet" as a logistic object can be considered in accordance with the Polish standard-PN-90/M-78200, which specifies that "a cargo pallet is a device intended for placing loads in it or on it and adapted to mechanized transport as a pallet load unit" [6]. However, this concept does not emphasize the function of the pallet from the point of view of the entire logistic chain, and yet it has a significant impact on the possibility of increasing its effectiveness, e.g., in relation to the scope of transport and storage activities. It is possible, e.g., thanks to the option of mechanization and automation of reloading and transport works or the reduction of mechanical damage to the goods/cargo in the process of transport and storage. Therefore, we shall adopt J.J. Coyle, E.J. Bardi, and C.J. Langley Jr.'s opinion that it is “a fundamental and essential element enabling manipulation of materials, the main function of which is to create a base that allows keeping individual inventory items together" [7]. Thus, in logistic processes, a wooden pallet is a logistic carrier that creates added value for goods/loads and at the same time is a part of the process itself.

\section{The Essence and Meaning Perception of Sustainable Development}

Despite many scientific publications, there are still many difficulties in interpreting the term "sustainable development", because in the literature it can be understood as: "sustainable", "durable", "stable", and finally "self-sustaining" [8]. The most widely accepted definition of this term is the most famous one, which was quoted in the report called "Our Common Future"- "to ensure that it meets the needs of the present without compromising the ability of future generations to meet their own needs" [9]. It should be noted, however, that already in the second half of the 1960s B. Ward (International Institute for Environment and Development) pointed out that "not only social and economic development and environmental protection are not mutually exclusive but should be applied jointly" [10]. Nevertheless, the literature also defines three important aspects related to the concept of sustainable development: environmental care, social welfare, and economic development, often referred to as the "Triple Bottom Line" [11].

Striving to achieve all these three goals that are only apparently contradictory, presupposes aiming for welfare economics, environmental quality, and social equality [12]. To put it simply, the idea of sustainable development is based on an empathetic balance of "the present" and "the future". This means that current economic development, which fully meets the needs and aspirations of the modern generation, cannot in any way contribute to limiting future generations from satisfying their needs and aspirations anytime and anywhere on Earth. As a result, such an approach is not based solely on balancing three dimensions of development, i.e., the constantly required economic growth, comprehensive environmental protection as full as possible social inclusion, but requires balancing sustainable development in time (multi-generational) dimension. Formally, the very term "sustainable development" was first used at the UN Conference in Stockholm (1972). However, at the time it was not included in the Stockholm Declaration [13]. This is because it mainly emphasized the negative consequences of all attempts to tame nature as a result of human economic activity, which leads to devastating and irreversible depletion of natural 
resources on Earth. It was only the quoted report of the World Commission on Environment and Development UN: "Our Common Future" that highlighted that "meeting the needs of the present-living generation must not threaten the possibilities" [14]. In the strategy of socio-economic growth of the European Union: "Europe 2020: a strategy for smart, sustainable and inclusive growth", on the other hand, the need for joint action of Members States to overcome the crisis and implement reforms to face the challenges of globalization, aging societies and the growing need for rational use of resources has been emphasized. It distinguishes three basic, mutually reinforcing priorities [14].

- Smart growth - a development based on knowledge and innovations

- Sustainable growth-a transformation towards a low-emission economy that is competitive and uses resources in an efficient manner

- Inclusive growth-supporting economy characterized by a high level of employment and ensuring economic, social, and territorial cohesion.

Finally, the document entitled Transforming our world: the 2030 Agenda for Sustainable Development, which was adopted by the United Nations, defines the model of sustainable development at the global level. It indicates that the contemporary modernization effort should focus on eliminating poverty in all its manifestations while pursuing a number of economic, social, and environmental goals $[15,16]$. The role of the sustainable development goals (SDGs) as signposts for formulating policies in the field of ecology and environmental protection until 2030 is also highlighted by, among others: Rakhmangulov A., Osintev O. [17], Calicioglu Ö., Bogdanski A. [18], de Toledo R., de Farias J., de Castro H., Putnik G., da Silca L. [19], Hassan M., Hed M., Kamilan I. [20].

\section{Materials and Methods}

The research goals, formulated for the purposes of the article, required primary research and literature studies. The following research methods were used:

- A critical analysis of the literature on the subject, which systematized the existing achievements regarding the life cycle of a pallet in sustainable logistics processes. It made it possible to outline the theoretical foundations of the topic under consideration, to quote the views and assessments expressed by specialists, as well as to define their significance for the topic undertaken in the study. The result of the literature studies was the identification of key elements of the TCO account of a reusable flat loading pallet;

- the method of quantitative research based on a questionnaire by which collected data on actual operating conditions loading pallets. At the same time, a level of cost awareness has been identified as part of the total cost of ownership (TCO) approach. The use of the questionnaire also allowed to collect and systematize the factors determining the operational dimension of the individual life cycle of a reusable flat loading pallet;

- a method of qualitative research based on an interview questionnaire, which was conducted among representatives of companies managing the largest pallet pools in the region of the Zachodniopomorskie Province in order to verify and detail the discussed issues;

- statistical analysis used to indicate trends, determine the size of shares, and the relationships between the variables and phenomena discussed in the article.

In addition to the literature analysis, the research discussed in this article uses data obtained by means of a questionnaire. The authors adopted the following model of scientific procedure, based on the common economic practice of recording costs of pallets as part of a one-off full write-off of their costs. Therefore, empirical research has been conducted based on an in-depth interview and the territorial scope of the interview covered the administrative borders of Zachodniopomorskie Province, Poland, and has been carried out using an interview questionnaire. The companies have been selected using a random selection among entities recorded by the Statistical Office in Szczecin. According to the Polish Classification of Activity (PKD), enterprises have been selected from the following 
sections: $\mathrm{C}$-manufacturing, $\mathrm{G}-$ wholesale and retail trade, $\mathrm{H}$ - transportation and storage, and $\mathrm{F}$-construction. The sample unit in the study consists of enterprises registered in Zachodniopomorskie Province, operating in the above-mentioned industry sectors that have been on the market for more than five years. A total number of 929 enterprises in Zachodniopomorskie Province met these criteria.

\section{Results}

The questionnaire was completed by 194 enterprises, which accounted for almost $21 \%(20.88 \%)$ of the sample and allowed for the formulation of conclusions about the entire general population. Therefore, the study has been conducted on a representative group of manufacturing and trade and service companies managing the largest pallet pools (Figure 1). Thus, according to the authors, a "pallet pool" should be treated as a pallet trading system, which consists in their co-use by entities (links) forming a supply chain (senders and recipients as well as logistic operators). At the same time, for efficient and effective management of pallet turnover, there always should be a dominant entity (a leader) in the entire chain which coordinates the management of this pool and which, due to the form of ownership of pallets themselves, may be an owned, mixed, or rented pool.

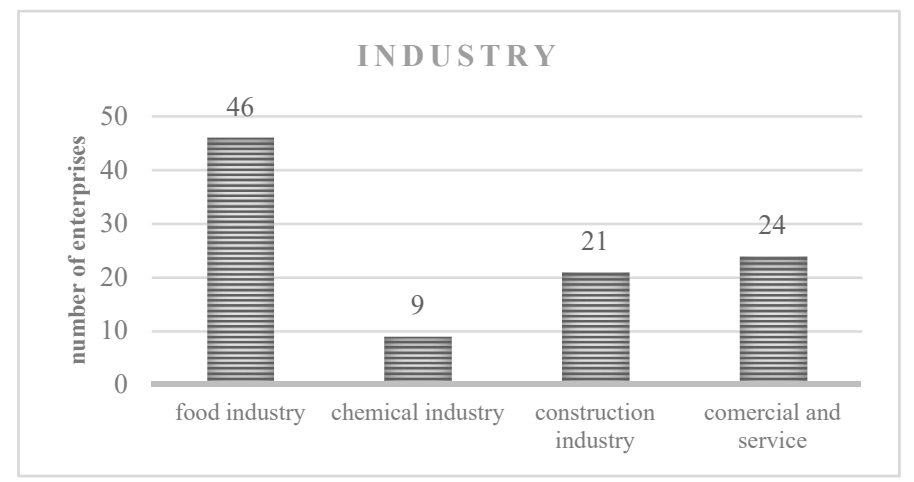

Figure 1. Bar chart of the industry structure of surveyed enterprises.

The analysis of structure by industry (Figure 1) of surveyed enterprises indicates that the largest number, as much as $46 \%$ of the enterprises participating in the survey, represented the food manufacturing industry, followed by $21 \%$ of enterprises from the construction industry, and the smallest group in terms of numbers were enterprises from the chemical industry, which constituted $9 \%$. The remaining $24 \%$ were enterprises from the following sectors: wholesale and retail trade as well as transport and storage.

The analysis of the structure of assessment of the level of importance of pallet economy (Figure 2), understood as: "all activities and processes of rational pallet turnover within an enterprise itself and in its connections within the entire supply chain, related to their acquisition, receipt, manipulation, transfer, and issuing, regardless of their technical condition and legal and economic effect in order to fully secure necessary organization of a mechanized or automated flow between individual organizational units and links in the supply chain", in manufacturing companies shows that more than half of them considered the importance of the pallet economy to be irrelevant or neutral ( $48.5 \%$ and $33.3 \%$, respectively), and it was of little importance for $12.1 \%$ of surveyed companies. As far as respondents from trade and service companies are concerned, more than half of them indicated that the pallet economy is very important and important for them $(15 \%$ and $45.6 \%$, respectively). However, a quarter of them indicated that it was not very important or irrelevant $(25.6 \%$ and $1.9 \%$, respectively), and for $11.9 \%$ of surveyed enterprises, it was neutral. It can therefore be concluded that the issue of proper management of pallet pool is addressed appropriately most of all in trade and service companies as in these enterprises process phases are longer and a pallet is subjected to a greater number of manipulations, warehouse and transport operations, and additionally, the requirement of rational pallet pool management is also dictated by the complexity of the structure of the distribution 
channel. As a result of the research, in the case of manufacturing companies, on the other hand, such low importance of pallet economy is significantly influenced by the fact that finished goods are most often placed on disposable pallet carriers, which makes them not only cheap but also lossy (they are not subject to registration).

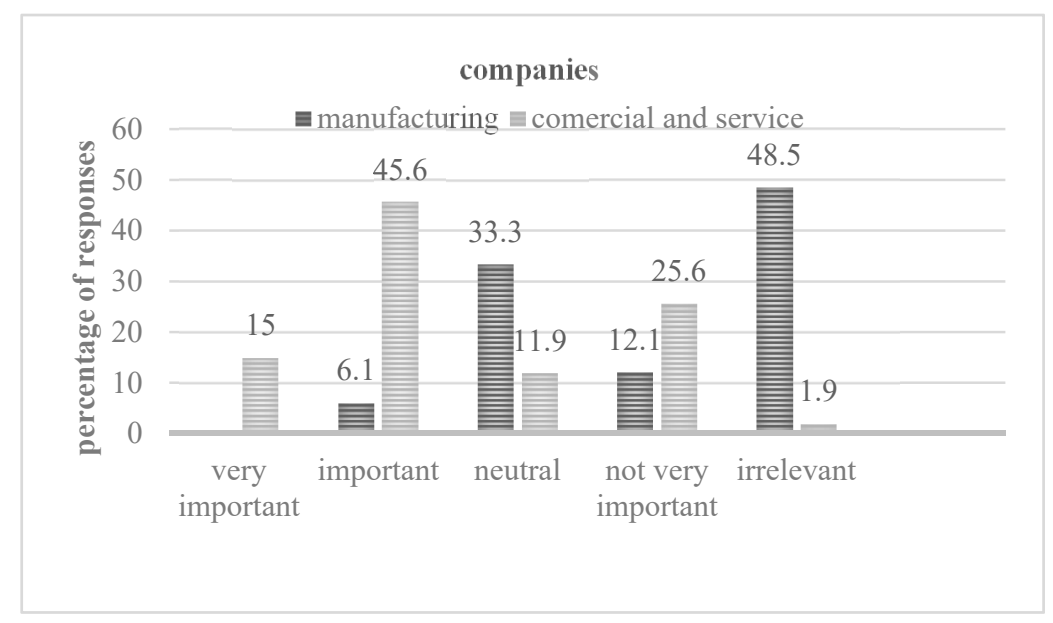

Figure 2. Bar chart of the importance of managing cargo pallets in the surveyed companies.

In order to determine sources of a specific approach to the importance of pallet economy, the share of palletized goods in surveyed manufacturing and trade and service enterprises has been examined. It turned out that it is similar in terms of the structure distribution, and the compartments are similar (Figure 3). However, in manufacturing companies, almost all goods were shipped on cargo pallets, while in the case of trade and service companies, the opposite was true, which may result primarily from the fragmentation of structure of customer (consumer) orders. The full form of a unitary pallet loading unit may be lost along the distribution channel due to displacement with very different customer requirements at different levels of the distribution channel, i.e., from a collective pallet loading unit to a non-palletized form. In trade and service companies, a pallet unit may result from the requests of customers waiting for goods, but also from the amount of goods they receive in a single delivery.

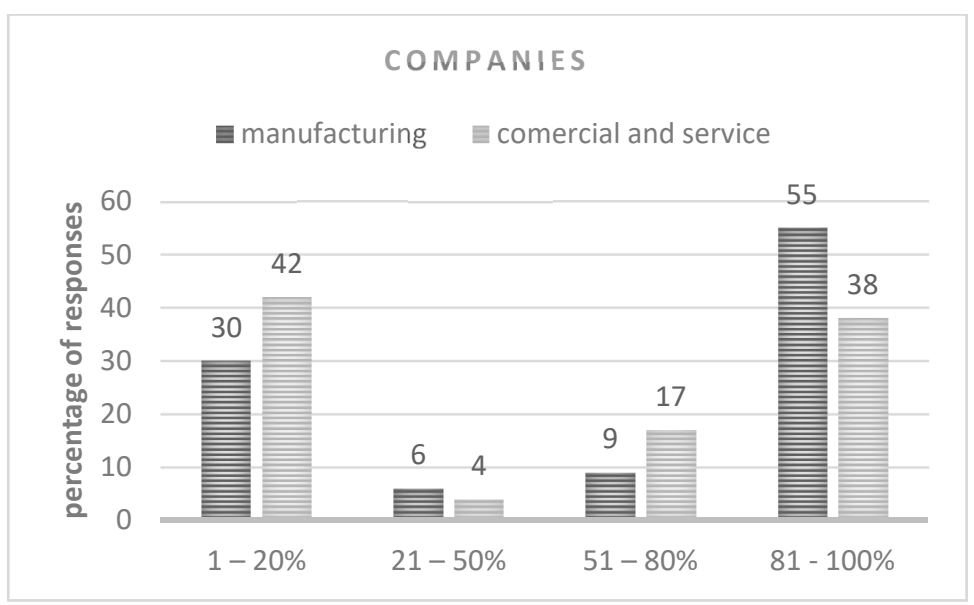

Figure 3. Bar chart of the structure of the share of palletized goods in surveyed companies.

Logistic operators participating in the study from the group of trade and service companies indicated that pallet pools they manage differ mainly in terms of material from which the pallets are made and in terms of such factors as, among others: licenses or supplying pallet pools only with new or used pallets. 
The analysis of the structure of participation of wooden pallets in the total volume of pallets in the surveyed enterprises (Figure 4) shows that the greatest number of enterprises, i.e., $68 \%$ of them, claims that wooden pallets constitute $81-100 \%$ of their total volume. In the case of $22 \%$ of respondents, this number lays between 1 and $20 \%$. While $7 \%$ of enterprises indicated that wooden pallets constitute between $51-80 \%$ of their total volume of pallets, only $2 \%$ of companies claim that wooden pallets account for $21-50 \%$ of their total volume. Therefore, the research confirmed the universality of the employment of wooden pallets and, consequently, their potential for optimization.

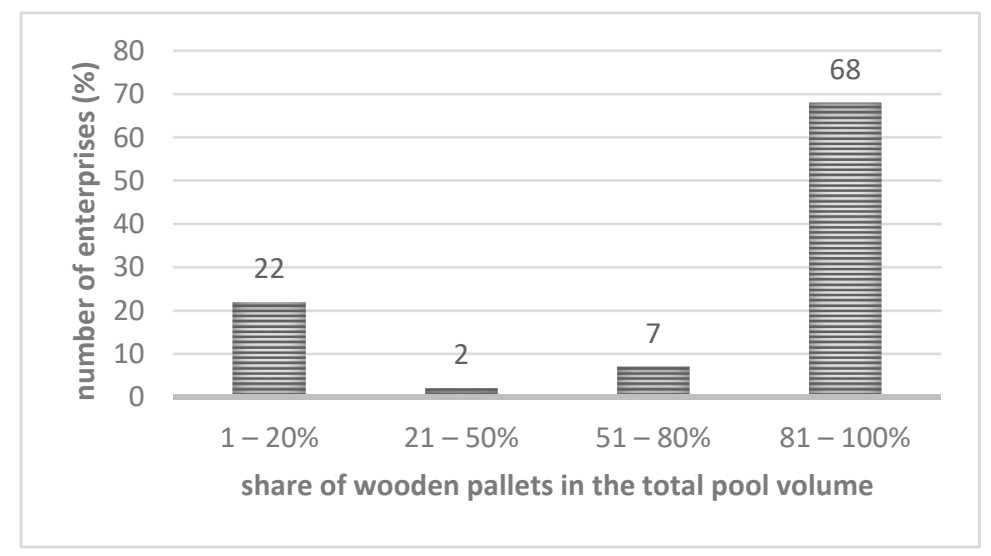

Figure 4. Bar chart showing the structure of participation of wooden pallets in the total volume of pallets in surveyed companies.

The analysis of the structure of a pallet trading system in surveyed companies (Figure 5) shows that most of them, i.e., $46 \%$ of the companies participating in the survey, confirmed that they use a mixed system (returnable and non-returnable one), in $28 \%$ of enterprises only a non-returnable pallet system is employed, and in $26 \%$ of participants only a returnable pallet system is used, and these are mainly manufacturing companies.

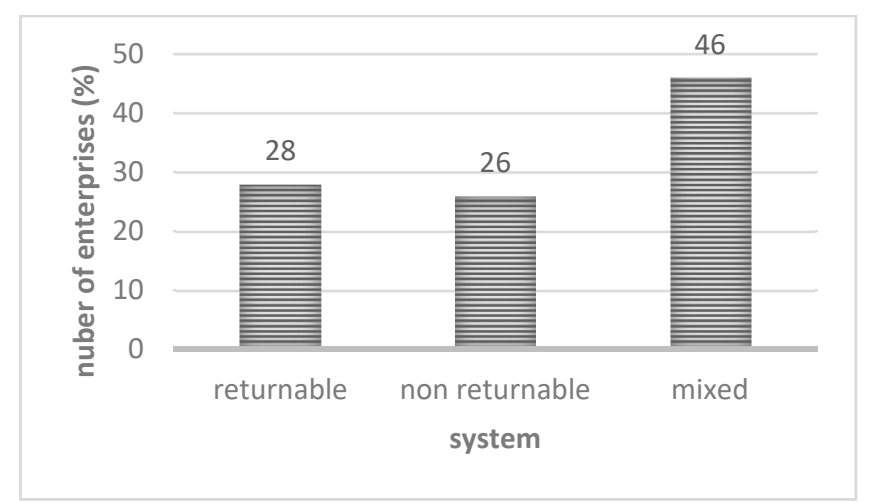

Figure 5. Bar chart of the structure according to the pallet trading system in the surveyed companies.

The analysis of the structure of criteria taken into account when purchasing new pallets (Figure 6) shows that the most important criterion for decision-makers is the price of pallets, followed by the possibility of negotiation of purchase price of pallet, quality guarantee, repair and service, and finally, the criterion of recyclability. The least significant criteria, on the other hand, enumerated by respondents were: having a license by the supplier, a manufacturer's area of operation, and financial stability of a manufacturer/recipient. 
Manufacturer's and supplier's price of the pallet

The ability to negotiation the price

Pallet quality guarantee

Warranty for pallet repair and service

Protection of the natural environment (ensuring recycling)

Terms and method of payment

Opinion on the market about the producer/supplier

Form of accepting orders

The producer's and supplier's financial stability

Confidence in the manufacturer/ supplier

Manufacturer's and supplier's area of operation

Possession of a license

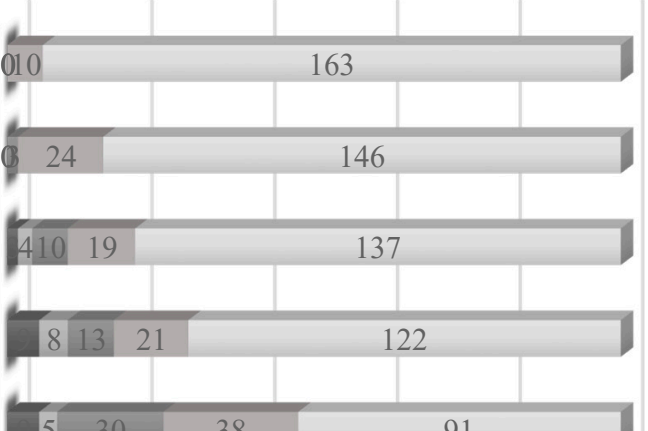

\begin{tabular}{ll|l}
5 & 30 & 38
\end{tabular}

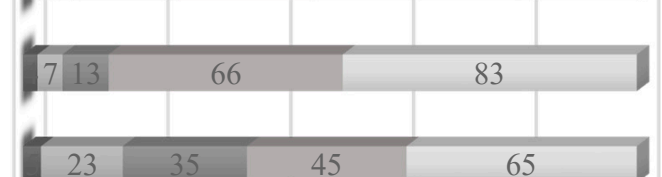

\begin{tabular}{l|l|l}
23 & 35 & 45
\end{tabular}

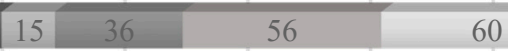

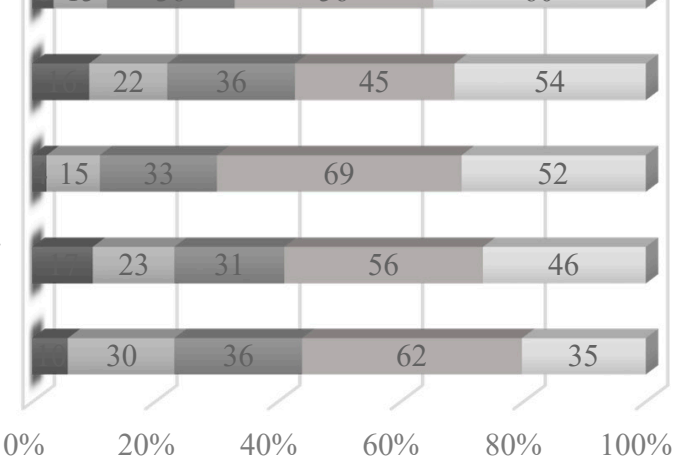$$
0 \%
$$

. 


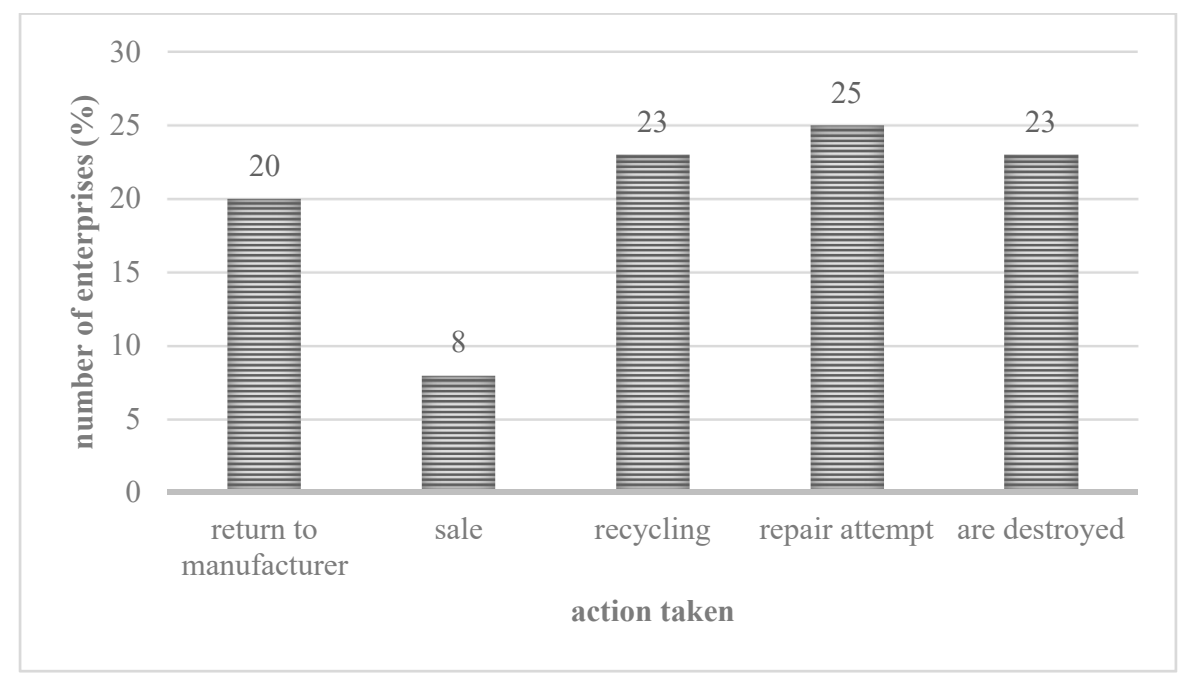

Figure 7. Bar chart of the procedure with used pallets in the surveyed enterprises.

\section{Discussion}

The concept of TCO for a cargo pallet in sustainable logistics processes allows to determine the total cost of its operation and to indicate activities increasing its service life. As a result, companies gain a useful instrument for determining the total cost of ownership palettes, which after all is in common use in the trade. It will also allow indicating the area of activities increasing its service life, which will result in better use of available pallets, cost savings, while reducing the negative effects on the natural environment, thus in line with the idea of sustainable development.

The concept of Total Cost of Ownership was presented, inter alia, in 1997 by Gartner Company in the USA [21] as a model for estimating all costs that may occur in the life cycle of an IT system, from acquiring the system, its use and maintenance, to its abolition [22]. From the point of view of a key stage in the life cycle of a reusable flat cargo pallet, which is its operation, a sustainable approach using the TCO formula certainly requires a complementary way of thinking and acting, which is precisely based on a sustainable approach. The correct understanding of the idea of the sustainable approach in economic (logistic) activity includes also awareness of responsibility for the impact on the present as well as on the future, which is shaped by people related to a specific business and operations carried out within it. The willingness to implement the idea of developing an approach in the operations of a company requires of course a comprehensive change in thinking and a completely different and modern approach. This is because for the most part, cutting down trees in order to obtain raw material for the production of cargo pallets is a phenomenon that evokes great social emotions. However, environmental economics and natural resources economics are developing extremely rapidly as part of economic sciences, and each evaluation of economic, social, or environmental activity is now carried out taking into account the following three basic aspects:

- Assessment of economic effects, including the amount of necessary investment and operating costs and their variability in the spatial and temporal system, as well as the impact of a project on the economic and social development of a commune (a city), a province (a region) or a country;

- assessment of the project's impact on the functioning of the social economy and natural processes;

- socio-ecological costs that generate various versions of project implementation or its abandonment.

However, despite its dynamic development, environmental economics and economics of natural resources have not yet developed universal methods or procedures for recording and estimating socio-ecological costs. Hence, in each study, it becomes necessary to 
recognize the direct and indirect effects of such an undertaking and to estimate related costs. Since every production of wooden pallets involves cutting down trees, it is always an intervention in the ecosystem. Ecologists point out that current practices will pose a threat to protected plants, animals, and birds. In Poland, the process of perceiving social and ecological effects of economic decisions began in the 1980s. These effects were at first only indicated, then estimated in physical units, and only since the last decade, they have been evaluated and included in the account in the form of social costs, mainly environmental external ones. Quantification of socio-ecological effects has been enabled by the development of methods of their evaluation and valuation [23].

The authors, on the basis of their other studies, believe that only some indicated examples of costs hidden in the concept of the total cost of ownership of a reusable wooden pallet are taken into consideration in the economic account rather than in accounting treatment of cost. However, they are of significant importance when assessing the benefits and risks of applying a balanced approach to the proposed formula of the total cost of ownership of a reusable flat cargo pallet. Therefore, in the authors' view, we can distinguish three key groups of costs, that make up the full form of costs related to a cargo pallet in its operation phase, i.e., total cost of possessionship, purchase price of the pallet from a supplier, total cost of maintenance, which is the total cost of maintenance its proper condition (operational readiness), and total cost of ownership, which constitutes the full TCO formula and includes the already mentioned total cost of possessionship of the pallet plus its maintenance in a proper technical condition throughout the entire operation phase and management of its withdrawal from the operation phase. For this reason, costs, i.e., costs of education, training, and development are of great importance. Thanks to the knowledge gained and used by the staff operating the pallet pool (warehouse workers, forklift truck operators, drivers) in the field of correct pallet picking, loading, reloading, unloading, as well as handling and storage, the probability of damage to pallets during the implementation of these activities is reduced. This has not only a social dimension, i.e., an increase in the awareness of workers who correctly perform transport and warehouse processes with the use of pallets, an increase in work safety, and thus care for the life and health of employees, but also an economic dimension, as efficient pallets (without signs of damage) do not require activities related to incurring costs, such as, for instance, additional repairs or servicing. Finally, it is also important for the environmental aspect since a smaller number of damaged pallets during handling or transport and storage processes means an extended duration of the operation phase of a pallet, which is, of course, related to a lack of demand for new raw material (deforestation) for the production of pallets. This, in turn, contributes to the conservation of natural resources. By protecting natural resources in this way, the natural heritage for present and future generations is preserved in economic (resource richness), environmental (afforestation maintenance), and social (ecological satisfaction) dimensions.

Adopting J.C. McLennan's philosophy [24], we can distinguish principles in a sustainable design of an operational life cycle of a reusable flat wooden pallet, and thus, these postulates can also be applied to the entire pallet management implemented in pallet pools. Conscious efforts to minimize consumption of energy and raw materials (the conservation principle) as much as possible will create an impulse to extend the life cycle of a pallet (keeping it in full operational readiness for the longest possible period of time). Respecting vital human needs (the human vitality principle) will result in undertaking all those activities that will not generate new and unjustified demand for raw material, the acquisition of which will be negatively perceived by individuals and society as a whole. Respect for the place of felling, namely the forest (the principle of ecosystem), is required as each tree in its forest community is an element of coexistence of fauna and flora. One must take full responsibility for future generations (the seven generation principle), which means taking such necessary measures that will allow future generations to freely use available natural resources at least to the same extent as the present generation does. Systemic thinking, i.e., thinking based on a holistic approach (the holistic principle), needs to be developed by 
responsible entities (all participants of the pallet market, namely manufacturers, users, service and disposal entities, and legalizing entities). The benefits of adopting the viewpoint based on TCO as well as the above-mentioned principles of sustainable development have been presented in Figure 8.

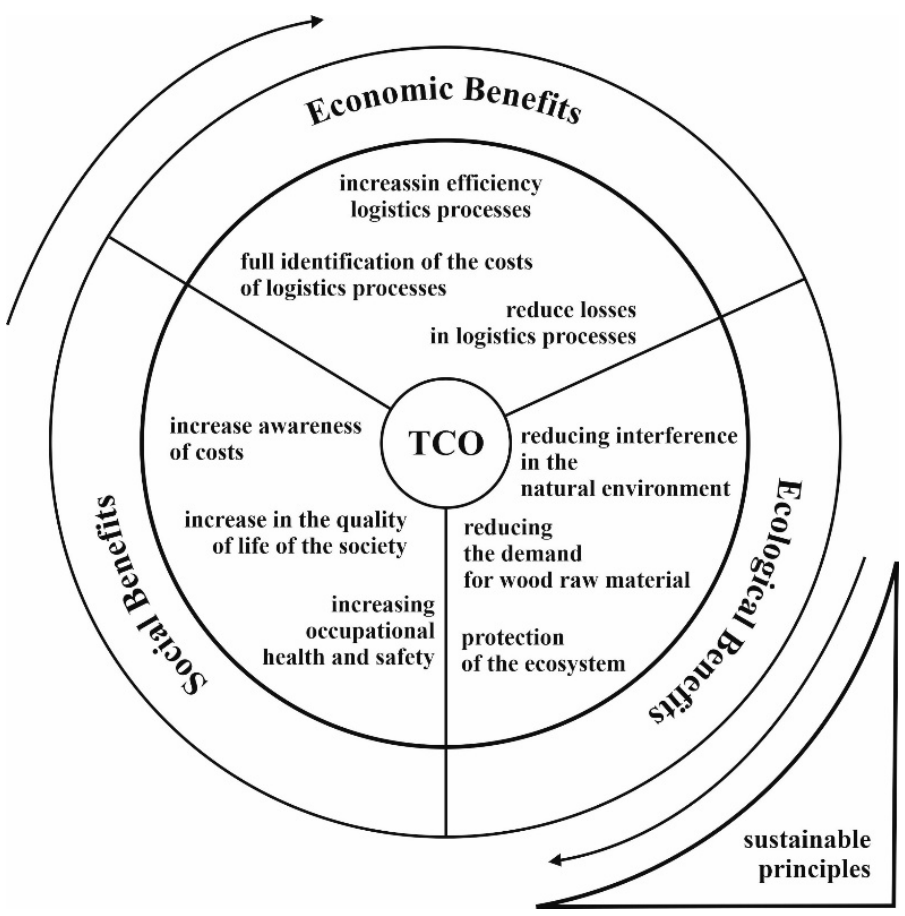

Figure 8. Benefits of using TCO.

The presented sustainable approach to TCO and the benefits it brings will be impossible without the transformation of consumer societies into sustainable ones. On one hand, an increased sales growth affects the demand for pallets, which obviously translates into increased profits of manufacturing and service companies from the sale of their goods, but on the other hand, the increase in demand for wood raw material indirectly negatively affects the ecosystem. Therefore, balancing the economic goals of each enterprise with social and environmental goals is a considerable challenge for modern humanity, national governments, management boards of manufacturing companies, social organizations, and other groups which exert influence on improving the quality of life of inhabitants on our planet.

\section{Conclusions}

The introduction of the concept of the total cost of ownership of a reusable flat cargo pallet to logistics practice in sustainable logistics processes undoubtedly allows for the acquisition of extremely useful knowledge for all participants in supply chains. It also favors the search for an integrated set of effective and efficient activities contributing significantly to extending the life cycle of a reusable flat cargo pallet. Such activities, carried out as part of pallet management, will support virtually all the principles of sustainable development (regardless of their enumerative set) because the very idea of sustainable development is closely related to the holistic approach to economic development, environmental protection, and supporting the well-being of society. Paying attention to the aspect of TCO in connection to a wooden pallet strengthens the potential for beneficial changes in the entire supply chain, as it includes cumulated features, such as: total cost of acquisition, putting into service, use, maintenance, and finally disposal of a pallet over a specific period of time. Therefore, the concept of a sustainable approach to the proposed form of the account of the total cost of ownership of a reusable flat cargo pallet can significantly support the implementation of the principles of sustainable development 
at the operational level. Decision-makers responsible for pallet management will see TCO as an extremely useful tool to manage pallet pools. This will allow them to implement a functional logistic strategy (focused on logistic functions performed) by indicating the area of such activities that increase the operational life of the pallet. Consequently, this will result in significant cost savings (economy of scale) and will reduce the negative impact on the natural environment (lower demand for wood raw material). Finally, the article highlights the high usefulness of TCO in relation to a wooden pallet, in determining and implementing the principles of sustainable development at the level of logistics operations, the possibility of noticing a large potential for reducing operating costs associated with extending the life cycle of the pallet, which further leads to favorable environmental and social effects.

Author Contributions: Conceptualization, M.J. and M.S.; methodology, M.J. and M.S.; software, M.S.; validation, M.J.; formal analysis, M.S.; investigation, M.J. and M.S.; resources, M.S.; data curation, M.S.; writing_original draft preparation, M.J. and M.S.; writing- review and editing, M.J. and M.S., visualization, M.J., M.S.; supervision, M.S., project administration, M.S.; funding acquisition, M.J. and M.S. All authors have read and agreed to the published version of the manuscript.

Funding: The project is financed within the framework of the program of the Minister of Science and Higher Education under the name "Regional Excellence Initiative" in the years 2019-2022; project number 001/RID/2018/19; the amount of financing PLN 10,684,000.00.

Institutional Review Board Statement: Not applicable.

Informed Consent Statement: Not applicable.

Conflicts of Interest: The authors declare that there is no conflict of interests regarding the publication of this paper.

\section{References}

1. Lindsey, T.C. Sustainable principles: Common values for achieving sustainability. J. Clean. Prod. 2011, 19, 561-565. [CrossRef]

2. Ben-Eli, M. Sustainability: Definition and Five Core Principles; The Sustainability Laboratory Publication: New York, NY, USA, 2015.

3. Value of LEED. Available online: www.leedonline.com (accessed on 20 April 2021).

4. What Is Breeam? Available online: www.breeam.com (accessed on 21 April 2021).

5. Taha, W.M. The Philosophy of Sustainable Design; Project: Introduction to LEED \& Sustainability Approach. Available online: www.researchgate.net/publication/312498123_The_Philosophy_Of_Sustainable_Design (accessed on 15 May 2021).

6. PN-90/M-78200. Palety Ładunkowe i Nadstawki Paletowe-Terminologia i Podział; Wydawnictwa Normalizacyjne ALFA: Warszawa, Poland, 1990.

7. Coyle, J.J.; Bardi, E.J.; Langley, C.J., Jr. Zarzadzanie Logistyczne; PWE: Warszawa, Poland, 2010; p. 373.

8. Shi, L.; Han, L.; Yang, F.; Gao, L. The Evolution of Sustainable Development Theory: Types, Goals, and Research Prospects. Eur. J. Sustain. Dev. 2020, 9, 7158. [CrossRef]

9. Brundtland, G.H. Our Common Future; The World Commission on Environment and Development: Oxford, UK, $1987 ;$ p. 54.

10. Zabłocki, G. Rozwój Zrównoważony, Idee, Efekty, Kontrowersje; Wydawnictwo UMK: Toruń, Poland, $2002 ;$ p. 9.

11. Norman, W.; MacDonald, C. Getting to the bottom of "Triple Bottom Line". Bus. Ethics Q. 2004, 14, 243-262. [CrossRef]

12. Elkington, J. Cannibals with Forks; Capstone Publishing Limited: Oxford, UK, 2002.

13. ul Haq, M. Report of the United Nations Conference on the Human Environment, Stockholm, Sweden, 5-16 June 1972; A/CONF.48/14 and corr.1. Available online: www.digitallibrary.un.org/record/523249 (accessed on 7 May 2021).

14. European Commission. Communication from the Commission Europe 2020. In A Strategy for Smart, Sustainable and Inclusive Growth; European Commission: Brussels, Belgium, 2010.

15. Resolution Adopted by the General Assembly on 25 September 2015. In Transforming Our World: The 2030 Agenda for Sustainable Development; A/RES/70/1. Available online: www.un.org/en/development/desa/population/migration/ generalassembly/docs/globalcompact/A_RES_70_1_E.pdf (accessed on 27 April 2021).

16. In Proceedings of the Report of the United Nations Conference on Environment and Development, Rio de Janeiro, Brazil, 3-14 June 1992; Volume I; A/CONF.151/26. Available online: www.un.org/esa/dsd/agenda21/Agenda\%2021.pdf (accessed on 9 May 2021).

17. Rakhmangulov, A.; Osintev, O. Green Logistics: Element of Sustainable Development Concept: Part 1. Nase More 2017, 64, 120-126. [CrossRef]

18. Calicioglu, O.; Bogdanski, A. Linking the bioeconomy to the 2030 sustainable development agenda: Can SDG indicators be used to monitor progress towards a sustainable bioeconomy? New Biotechnol. 2021, 61, 40-49. [CrossRef] [PubMed] 
19. Toledo, R.; Farias, J.; Castro, H.; Putnik, G.; Dilva, L. Is the incorporation of sustainability issues and Sustainable Development Goals in project management a catalyst for sustainable project delivery? Int. J. Sustain. Dev. World Ecol. 2021, 3, 1-11. [CrossRef]

20. Hassan, M.; Hed, N.; Kamilan, I. Parliamentary reforms and Sustainable Development Goals (SDG): The way forward for an inclusive and sustainable parliament. J. Legis. Stud. 2021, 3, 1-28. [CrossRef]

21. Castellani, S.; Grasso, A.; O'Neill, J.; Tolmie, P. Total cost of ownership: Issues around reducing cost of support in a manufacturing organization case. In Proceedings of the Seventh IEEE International Conference on E-Commerce Technology Workshops, Proceedings Paper, Munich, Germany, 19 July 2005; pp. 122-130.

22. Morssinkhof, S.; Wouters, M.; Warlop, L. Effects of providing total cost of ownership information on attribute weights in purchasing decisions. J. Purch. Supply Manag. 2011, 17, 132-142. [CrossRef]

23. Gontarz, A.; Hampl, D.; Weiss, L.; Wegener, K. Resource Consumption Monitoring in Manufacturing Environments. Procedia CIRP 2015, 26, 264-269. [CrossRef]

24. McLennan, J.F. The Philosophy od Sustainable Design; ECOTone: Kansas City, MO, USA, 2004. 